\title{
Why Does the Law of One Price Fail? An Experiment on Index Mutual Funds*
}

\author{
James J. Choi, \\ Yale School of Management, 135 Prospect Street, P.O. Box 208200, New Haven, CT 06520-8200, \\ james.choi@yale.edu \\ David Laibson, and \\ Department of Economics, Harvard University, Littauer M-14, Cambridge, MA 02138, \\ dlaibson@harvard.edu \\ Brigitte C. Madrian \\ Kennedy School of Government, Harvard University, 79 JFK Street, Cambridge, MA 02138, \\ brigitte_madrian@harvard.edu
}

\begin{abstract}
We conduct an experiment to evaluate why individuals invest in high-fee index funds. In our experiments, subjects allocate $\$ 10,000$ across four S\&P 500 index funds and are rewarded for their portfolio's subsequent return. Subjects overwhelmingly fail to minimize fees. We can reject the hypothesis that subjects buy high-fee index funds because of bundled non-portfolio services. Search costs for fees matter, but even when we eliminate these costs, fees are not minimized. Instead, subjects place high weight on annualized returns since inception. Fees paid decrease with financial literacy. Interestingly, subjects who choose high-fee funds sense they are making a mistake.
\end{abstract}

Mutual fund fees vary by an order of magnitude across firms, even though the industry has hundreds of competing providers. There is scant evidence that more expensive funds pick securities well enough to offset their higher fees (e.g. Carhart, 1997; Gruber, 1996). Hence, it is puzzling that competition has not eliminated high-fee funds. The puzzle is especially acute in the index fund market, where funds tracking a given index offer virtually identical portfolio returns before fees, but price dispersion is no smaller than in the actively managed fund market (Hortaçsu and Syverson, 2004). In 2007, retail S\&P 500 index fund investors paid \$206 million more in expenses (not including sales loads) than they would have if their entire S\&P 500 index fund balance were in the retail no-load S\&P 500 index fund with the lowest expense ratio.

Some researchers have argued that high index fund fees reduce investor welfare, since they are sustained by investors' search costs (Sirri and Tufano, 1998; Hortaçsu and Syverson, 2004) or mistakes abetted by mutual fund marketing (Elton, Gruber, and Busse, 2004; Barber, Odean, and Zheng, 2005; Cronqvist, 2006). The mutual fund industry has countered that "S\&P 500 index funds themselves are not commodities. These funds differ from one another through

\footnotetext{
*We are indebted to Anna Blank, David Borden, Carlos Caro, Ananya Chakravarti, Keith Ericson, Christina Jenq, Shih En Lu, Dina Mishra, Kelly Shue, Dmitry Taubinsky, Chelsea Zhang, Fan Zhang, and Eric Zwick for their excellent research assistance. We are grateful to Sally Zeckhauser, John W. Nolan, Ken Toy, and Thomas E. Vautin for facilitating the experiment with Harvard staff. We thank Jeff Brown, Gideon Saar, and seminar participants at the Boston Fed, NBER, University of Connecticut, University of Maryland, University of Pennsylvania, and Yale for helpful comments. We acknowledge individual and collective financial support from the National Institute on Aging (grants R01-AG021650 and T32-AG00186) and the U.S. Social Security Administration through grant \#10-P-98363-2 to the National Bureau of Economic Research as part of the SSA Retirement Research Consortium. The findings and conclusions expressed are solely those of the authors and do not represent the views of NIA, SSA, any other agency of the Federal Government, or the NBER. Choi acknowledges financial support from the Mustard Seed Foundation.
} 
the services that are packaged with their securities portfolios and through other characteristics" (Collins, 2005). These non-portfolio services include financial advice, customer service, and discounted access to complementary investment instruments. Thus, investors in expensive funds may receive higher quality non-portfolio services that fairly compensate them for their lower financial returns.

Elton, Gruber, and Busse (2004) find no evidence for the non-portfolio service hypothesis when they regress index fund net inflows on proxies for service quality. There is no significant correlation of flows with service quality rankings from a Dalbar survey, as well as with several other measures of non-portfolio service quality. Inflows are positively related to the number of Morningstar categories covered by the fund's family, perhaps suggesting a demand for complementary investment instruments, but simply investing in low-expense or high-pastalpha funds delivers superior future portfolio returns and a higher number of Morningstar categories in the selected families. However, non-portfolio services and their quality are difficult to measure. It is therefore possible that high-fee index fund investors are receiving services not captured by Elton, Gruber, and Busse's proxies. Furthermore, even if it were established that investors were receiving some extra services in exchange for lower portfolio returns, it would remain unclear whether a rational investor would pay such a high price for these services.

This paper reports new experimental evidence that sheds light on whether rational demand for non-portfolio services can account for the existence of high-fee index funds. We asked 730 experimental subjects to allocate $\$ 10,000$ among four real S\&P 500 index funds. All subjects received the funds' prospectuses. To make choices incentive-compatible, subjects' expected payments depended on the actual returns of their portfolios over a specified time period after the experimental session. We offered especially large incentives in one version of our experiment; for each of the 391 subjects in this implementation, choosing the most expensive portfolio instead of the least expensive portfolio reduced his or her wealth by $\$ 94$.

Our experimental setting gives us direct control of non-portfolio services. Because the investments were intermediated by the experimenters (and not by the fund companies themselves), no non-portfolio services were provided. Thus, the optimal portfolio allocates everything to the lowest-cost index fund.

The composition of our subject pool made it more likely that we would find support for rational theories. Our largest subject group (which received the largest incentives) consists of Harvard staff members-all white collar non-faculty employees-who on average have many years of experience managing their personal finances. Furthermore, $88 \%$ have a college degree, and $60 \%$ have graduate school education as well. Our next largest group of participants consists of MBA students from Wharton. The remaining subjects are college students recruited on the Harvard campus. Our MBA subjects report an average combined SAT score of 1453, which is at the 98th percentile nationally, and our college subjects report an average score of 1499, which is at the 99th percentile. When we measure financial literacy directly, we find that all three subject groups are more knowledgeable than the typical American investor.

Despite eliminating non-portfolio services, we find that almost none of the subjects minimized fees. In our main experimental group, staff, MBA students, and college students respectively paid 201, 112, and 122 basis points more in fees on average than they needed to. Staff and college students reported in debriefing surveys that fees played relatively little role in their portfolio decision. MBAs claimed that fees were the most important decision factor for them, yet their portfolio fees are not statistically lower than college students' fees. All subject groups reported placing high weight on past returns. This would be sensible if the past returns in the prospectuses were measured over the same horizon. But the mutual funds we offered had 
differing fund inception dates and prospectus publishing cycles. In fact, we constructed our fund menus so that the longest-horizon annualized historical returns reported in the prospectuses are positively correlated with fees. As a result, chasing the past returns reported in the prospectuses lowered future expected returns.

Given that subjects are making mistakes in their portfolio choices, are there information interventions that can alter the magnitude and frequency of these mistakes? We test three such treatments by comparing subjects who were randomly assigned to receive only the fund prospectuses to subjects who were randomly assigned to receive the prospectuses plus additional information.

In one treatment condition, we gave subjects a one-page "cheat sheet" that summarized the funds' front-end loads and expense ratios. If the cost of finding the fees in the prospectus is the principal reason why our subjects invested in high-fee index funds, then receiving the fees sheet prior to making the portfolio decision should cause them to pay nearly the minimum possible fees.

In a second treatment condition, we distributed one page of answers to frequently asked questions (FAQs) about S\&P 500 index funds. The sheet told subjects that all S\&P 500 index funds seek to make their pre-fee investment returns approximate the S\&P 500's return. If a failure to understand the commodity nature of S\&P 500 index funds lies behind our subjects' decisions, then this FAQ intervention may mitigate portfolio choice errors.

Our third treatment made salient a particular historical return, as some mutual fund advertising strives to do (Jain and Wu, 2000; Sapp and Tiwari, 2004; Mullainathan and Shleifer, 2005; Cronqvist, 2006). Subjects in this condition received a summary sheet that showed the longesthorizon historical annualized return reported in each fund's prospectus-usually the fund's return since inception. As noted previously, we constructed our fund menus so that these longhorizon historical returns are positively correlated with fees.

We find that eliminating search costs for fees improved portfolio allocations, but the effect is modest. Among those receiving the one-page fee summary sheet, $90 \%$ of staff and college students and $81 \%$ of MBAs still failed to minimize index fund fees. It thus appears that search costs play some role in but do not fully account for the willingness to hold high-fee index funds. When we explained what S\&P 500 index funds are in the FAQ treatment, portfolio fees dropped modestly, but the statistical significance of this drop is marginal. Finally, highlighting misleading long-horizon historical returns by providing the returns summary sheet caused students to allocate more money to the fund with the highest long-horizon historical return. Staff portfolios, however, did not respond to the returns summary intervention. It appears that the staff members who did not get the summary sheet were motivated enough to find this information without our help, precluding an effect from receiving the special sheet with highlighted returns.

We conclude that mistakes driven by financial illiteracy are the primary source of the demand for high-fee index funds. Interestingly, investors in high-cost index funds have some sense that they are making a mistake. Those paying higher fees also reported having less confidence that their choice was optimal for them, a higher anticipated likelihood of changing their portfolio in response to professional investment advice, and less general investment knowledge. Our results add to a growing body of evidence that individual investors make suboptimal asset allocation decisions (e.g., Benartzi and Thaler, 2001; Cronqvist and Thaler, 2004; Choi, Laibson, and Madrian, 2005; Choi, Laibson, Madrian, and Metrick, 2007; Cronqvist, 2006; Barber, Odean, and Zheng, 2005). 
The paper proceeds as follows. Section I describes our experimental design. Section II discusses the characteristics of our subject pool. Section III describes the main results from the experiment, and Section IV interprets the results. Section V explores the link between portfolio choices and subject characteristics. We conclude in Section VI.

\section{Section I. S\&P 500 Index Fund Experiment Design}

We ran two versions of our investment experiment. During the summer of 2005, we recruited MBA students at Wharton and college students at Harvard to participate. ${ }^{1}$ Harvard staff members were recruited for the experiment in the summer of 2007. In both versions, subjects allocated a hypothetical $\$ 10,000$ across four real S\&P 500 index funds. They received a modest fee up-front for participating and were eligible for an additional delayed payment that depended on how their chosen portfolio actually performed after the experimental session. By basing payments on the future returns of real funds (instead of artificial funds constructed for the experiment), we made it clear to subjects that we had no private information about how their portfolio choices would affect their payments.

The two groups of student subjects were told that one participant would be selected at random to win any positive return his or her chosen allocation earned from September 1, 2005 through August 30, 2006. Implementing the portfolio-based payment as a call option with a strike price of $\$ 10,000$ rather than a fixed percentage of the final portfolio value increased the marginal impact of subjects' choices on their expected payment while keeping the experimental budget reasonable.

In response to concerns that our student results are driven by the subjects' low expected portfolio payout, we promised every subject in the 2007 Harvard staff experiment the upside return of their $\$ 10,000$ portfolio, but only for the month of September 2007 rather than for a full year. We were writing a call option on $\$ 4$ million of underlying securities, so we hedged our short position by buying calls on our own outside account. Because of the high cost of this hedge, we used an investment horizon of only one month for the staff experiment.

All subjects received photocopies of four S\&P 500 index funds' prospectuses. Prospectuses are often the only document sent to potential investors requesting information about a fund. Subjects also received a sheet on which they recorded their chosen investment allocation. Participants had to satisfy the real-life minimum opening balance requirement for any fund to which they made an allocation. Appendix A reproduces the investment choice sheet given to staff subjects. ${ }^{2}$

We divided our participants into four information conditions. The prospectus-only group received only the choice sheet and prospectuses for each of the funds. The first of the three randomly selected treatment groups also received a one-page "fees sheet" (staff version reproduced in Appendix B). The fees sheet explained that mutual funds charge fees, showed how to calculate the impact of loads and expense ratios on portfolio value, and listed the load, expense ratio, and dollar cost of the load and expense ratio for a one-year $\$ 10,000$ investment in each of the four funds participants could select. All of the fees sheet information was also contained in the prospectuses. If subject choices in the prospectus-only condition reflect utilization of all relevant information in the prospectuses, then the fees treatment group should on average select the same portfolio as the prospectus-only group.

\footnotetext{
${ }^{1}$ The MBA students were mostly first-year students recruited during their pre-term orientation. Therefore, they had completed very little (if any) MBA coursework at the time of the experiment. Nonetheless, we believe this group to be very sophisticated relative to the typical individual investor.

${ }^{2}$ Materials given to student subjects were similar to the staff materials. All experimental materials, including prospectuses, may be downloaded from the first author's website.
} 
The returns treatment group received the choice sheet, prospectuses, and a one-page "returns sheet" (staff version reproduced in Appendix C) listing the longest-horizon annualized historical returns net of all fees (including the load) reported in each of the four funds' prospectuses. For student subjects, these long-horizon returns were all returns since the fund's inception. For staff subjects, three of the long-horizon returns were returns since inception, and one was a ten-year return. (The reason for this discrepancy is explained later in this section.) The sheet showed the dates over which the returns were calculated, as well as the disclaimer, "Past performance is no guarantee of future results." The date ranges of the long-horizon returns varied across funds. Thus, long-horizon return variation was driven almost entirely by the S\&P 500 's performance during the date range and should be ignored when predicting future relative returns. There is extensive evidence that mutual fund investors chase past returns (Hendricks, Patel, and Zeckhauser, 1993; Ippolito, 1992; Sirri and Tufano, 1998; Chevalier and Ellison, 1997), but the rationality of such behavior is a subject of debate (Gruber, 1996; Carhart, 1997; Zheng, 1999; Sapp and Tiwari, 2004; Berk and Green, 2004). Our experiment tests returns-chasing rationality by varying exposure to past return information that should have no effect on fund allocation decisions.

In addition to the fees and returns treatment groups described above, the Harvard staff experiment also included a frequently asked questions (FAQ) treatment condition. In this condition, subjects received the choice sheet, prospectuses, and one page of answers to the following questions (reproduced in Appendix D): (1) What is a mutual fund? (2) What is an $\mathrm{S} \& \mathrm{P} 500$ index fund? (3) What is the $\mathrm{S} \& \mathrm{P} 500$ Index? If prospectus-only subjects choose highcost funds simply because they do not understand that all S\&P 500 index funds seek to imitate the same portfolio's return, supplying these answers may shift subjects' portfolios to lowercost funds.

Subjects in all groups were given as much time as they wanted to make their investment allocations. They were not allowed to confer with each other. After participants submitted their investment allocation, they completed a debriefing survey that measured demographics, financial literacy, and motivations behind their portfolio choice (staff version reproduced in Appendix E). Students were also asked for their SAT scores.

We used the following criteria to choose the four S\&P 500 index funds offered to student subjects: (1) they were front-end load funds with wide variation in the total fees charged; (2) they were less than 10 years old, and hence reported annualized returns since fund inception in their prospectus; (3) annualized returns since inception were positively correlated with fees across funds; and (4) their prospectus was available as a PDF document online.

We wanted wide variation in the fees charged by the funds we offered so that subjects' decisions would meaningfully affect their expected returns. The largest source of S\&P 500 index fund fee variation is their loads, which vary in the CRSP mutual fund database from $0 \%$ to $5.75 \%$ of invested funds. There is also substantial variation in annual expense ratios, which vary from 6 to 200 basis points. We restricted the set of funds under consideration to those with loads because we did not want to confound sensitivity to total fees with sensitivity to the mere presence of a load. We opted to include only front-end load funds (rather than also offering backend load funds) in order to facilitate explaining the funds' fees on only one page. Barber, Odean, and Zheng (2005) present evidence that mutual fund investors are more sensitive to loads than expense ratios. Therefore, subjects are likely to be more sensitive to our experiment's fund fees than to fees in the general index fund universe, where there are many no-load funds.

By requiring that our funds be less than 10 years old, we ensured that their prospectuses reported annualized returns since inception. Because we wanted to distinguish irrational returns-chasing 
behavior from rational fee-avoiding behavior, we searched for a fund menu where fees were positively correlated with annualized returns since inception.

After imposing the above criteria, the set of suitable S\&P 500 index funds was remarkably small. The four funds we selected are the Allegiant S\&P 500 Index Fund, the Mason Street Index 500 Stock Fund, the Morgan Stanley S\&P 500 Index Fund, and the UBS S\&P 500 Index Fund. For all four funds, we specified that subjects could only invest in the Class A shares. The funds, their ticker symbols, minimum opening balance requirements, and fees are listed in Panel A of Table 1. These numbers are taken from the most recent prospectuses available at the time of the experiment, which listed returns through December 31, 2003.

The expense ratio across the four funds varies from $0.59 \%$ to $0.80 \%$, and the load varies from $2.50 \%$ to $5.25 \% .^{3}$ The total annual fee (expense ratio plus front-end load) on a $\$ 10,000$ investment held for one year varies from a low of $\$ 309$ for the Allegiant fund to a high of $\$ 589$ for the Morgan Stanley fund. ${ }^{4}$ Though the Allegiant fund is the lowest-cost fund, the total fee for the UBS fund is only \$11 more. The other two, the Mason Street and Morgan Stanley funds, have substantially higher loads and expense ratios.

Panel A of Table 2 lists the fund returns reported in the prospectuses. The annualized returns since inception net of all fees across the four funds vary from a low of $1.3 \%$ for the Allegiant fund to a high of 5.9\% for the Mason Street fund. All four funds were established during a 19month window, but the S\&P 500 Index level ranged from 757 at the Mason Street fund's inception to 1047 at the Allegiant fund's inception. This variation in the S\&P 500 Index value at inception is largely responsible for the differences in the reported return since inception. Note that the fund with the highest annualized return since inception (the Mason Street fund) is one of the two high-cost funds, whereas the fund with the lowest reported return since inception (the Allegiant fund) is the lowest-cost fund. The last two columns of Table 2 show that even excluding the impact of the sales load, the low-cost Allegiant fund has the highest historical alpha during the period in which all four funds were operational, and the funds' tracking errors are nearly identical.

We wanted to offer the same funds to the staff subjects, who were recruited two years after the student subjects. However, the Mason Street fund was acquired by American Century Investments in 2006 and incorporated into an existing American Century index fund. Therefore, we replaced the Mason Street fund with the Phoenix Insight Index Fund, which also has high fees and historical returns. Panel B of Table 1 shows the characteristics of the funds offered to staff subjects, as listed in the most recent prospectus available at the time of the experimental sessions.

The three funds offered to both students and staff-the Allegiant, Morgan Stanley, and UBS funds-have similar expense ratios and front-end loads in 2005 and 2007. The total fees paid by staff subjects are generally lower, however, because their investment horizon was only one month, so they were charged for only one month of ongoing expenses rather than a full year. The liquidation of staff subjects' portfolio after one month also triggered a $1 \%$ earlyredemption fee for the UBS fund, raising its cost to staff subjects relative to its cost to student

\footnotetext{
${ }^{3}$ The expense ratio associated with each of these funds is not unambiguous because all four funds have in the past waived part of their stated expenses on an ad hoc basis each year. In this paper, we use the expense ratio from the prior year after any expense waivers, as stated in the prospectus, unless the fund guarantees the waiver level in the following year. Morningstar uses net-of-waiver expense ratios to rate funds. See Christoffersen (2001) for a discussion of mutual fund fee waivers.

${ }^{4}$ We calculate fees on a one-year $\$ 10,000$ investment with the formula $\$ 10,000 \times($ expense ratio + load) for simplicity, since that was the total fee implicitly presented to subjects in the fees treatment condition. Calculating fees using the formula $(\$ 10,000 \times 10 a d)+(\$ 10,000$ $\times(1-$ load $) \times$ expense ratio) yields almost identical results for all of the paper's analyses. We use the formula $\$ 10,000 \times($ expense ratio/ $12+$ load) to calculate fees on a one-month investment.
} 
subjects. Whereas the Morgan Stanley fund is the most expensive fund offered to student subjects, the Phoenix fund is the most expensive fund offered to staff subjects.

Because the Phoenix fund had been in operation for more than ten years at the time of the staff experiment, its prospectus did not list an annualized return since inception, but instead listed a ten-year historical return. We reported this ten-year return for the Phoenix fund on the staff subjects' returns sheet. The Phoenix fund's 7.3\% ten-year return is significantly higher than the other funds' returns since inception, which are between $3.1 \%$ and $3.8 \%$. In addition, the 9.8\% one-year historical return (including the sales load) listed in the Phoenix fund's prospectus is much higher than the other funds' one-year returns of less than $2 \%$. This is because the most recent prospectus for the Phoenix fund listed returns through 2006 (a good year for the market), whereas the other prospectuses only listed returns through $2005 .{ }^{5}$ In the last three columns, we find that despite its high current expense ratio, the Phoenix fund has the highest historical alpha. It also has the highest tracking error. These findings are due to the fact that the Phoenix fund's expense ratio used to be much lower and changed multiple times during its history. ${ }^{6}$ During September 2007 (the investment period that determined staff payouts), the Phoenix fund had the lowest return (3.66\%) and the Allegiant fund had the highest return (3.74\%), as predicted by the current expense ratios.

Recall that every staff subject was effectively given a call option whose strike price was $\$ 10,000$ and whose underlying asset's initial value was $\$ 10,000 \times(1-$ portfolio load $)$. This created large incentives for the staff subjects to make optimal choices. Based on the yield of the 30day Treasury bill and the implied S\&P 500 volatility given by the Chicago Board Options Exchange Volatility Index (VIX) at the close of August 21, 2007-the day before the first staff sessions began - the Black-Scholes value of allocating $100 \%$ to the Allegiant fund was $\$ 170$, whereas the value of allocating $100 \%$ to the Phoenix fund was $\$ 76$. Therefore, each staff subject stood to gain $\$ 94$ by moving from the worst portfolio to the best portfolio.

\section{Section II. Subject Characteristics}

Our subjects are 391 Harvard staff members, 252 Wharton MBA and Ph.D. students, and 87 students recruited primarily on the Harvard campus. Although we aimed to recruit only MBA subjects on the Wharton campus, we did not explicitly prohibit non-MBA students from participating in the experiment, so our Wharton campus subject pool included 15 college students and two Ph.D. students. ${ }^{7}$ We group the MBA students with the Ph.D. students and refer to them collectively as the "MBA sample." We group the college students on the Wharton campus with the student subjects at the Harvard campus and refer to them collectively as the "college sample."

Table 3 gives summary statistics on our subject pools. The average staff subject is about 40 years old, which means that they typically have a couple of decades of experience managing their personal finances. As expected, the student subjects are substantially younger. The majority of our staff subjects are female, whereas both the college and MBA samples have male majorities. The staff subjects are very well-educated: $88 \%$ have a college degree (almost all of these are bachelor's degrees, not associate's degrees), and $60 \%$ have some graduate education or a graduate degree. The "college" sample includes a few high school students who

\footnotetext{
5 The 2006 S\&P 500 return was $15.78 \%$, in contrast to the Phoenix fund's $16.47 \%$ return before loads. The end of the prospectus reveals in a long table that excluding a non-recurring payment by the fund's former administrator, the fund's 2006 return was only $15.18 \%$. The Phoenix fund's annual report discloses that the payment was made because the administrator had previously been charging Phoenix more than had been contractually agreed upon. Even if one were to believe that similar payments were to be regular occurrences for Phoenix investors going forward, the expected payment over a one-month investment horizon is surely swamped by the fund's $5.75 \%$ load.

${ }^{6}$ For example, the annualized expense ratio was $0.45 \%$ after fee waivers in the second half of 2005 .

${ }^{7}$ We confirmed the Harvard staff and Wharton student affiliations by checking their school-issued identification cards.
} 
were taking summer school classes on campus, as well as a few college graduates. Both MBAs and college subjects report extraordinarily high average SAT scores (the 98th and 99th percentiles, respectively). ${ }^{8}$

Every subject group is more financially literate than the typical American investor sampled in the John Hancock Defined Contribution Plan Survey (John Hancock Financial Services, 2002). Only $8 \%$ of John Hancock respondents knew what kinds of assets a money market fund holds, versus $21 \%$ of our staff subjects, $40 \%$ of our MBA subjects, and $15 \%$ of our college subjects. ${ }^{9}$ John Hancock respondents on average thought that the stock of their own company was less risky than an equity mutual fund; on a 5-point scale, the average risk rating was 3.1 for employer stock and 3.6 for an equity mutual fund. In contrast, all ten of our experimental groups (four staff groups, three MBA groups, and three college student groups) on average correctly rated a typical Fortune 500 stock as more risky than an equity mutual fund. However, this second comparison is potentially confounded by the fact that John Hancock respondents were asked about the stock of their own employer, whereas our subjects were asked about the stock of a typical Fortune 500 company.

Through the luck of the draw, staff subjects in the fees treatment group are younger, more likely to be female, and more educated than the other staff subjects. We will show in Section IV that our treatment estimates are robust to controlling for these demographic differences. In addition, prospectus-only MBAs are less financially knowledgeable than other MBAs when judged by their knowledge of what a money market fund's investments are. In unreported regressions, we find that controlling for whether this question was answered correctly does not qualitatively change our inference about the MBA fees treatment effect and strengthens the statistical significance of the returns treatment effect.

Consistent with their high-powered incentives, staff subjects reported spending the most time reading the prospectuses: about 14 minutes on average. MBAs reported spending about 12 minutes reading the prospectuses, and college students reported spending about 9 minutes. ${ }^{10}$ Students in both prospectus-only groups spent more time reading the prospectuses than the treatment groups, which seems sensible given that they received only the prospectuses and no additional materials. This pattern is reversed among staff subjects, who spent the least time reading the prospectuses when in the prospectus-only group, but the differences between the staff prospectus-only group and the other staff treatment groups are not statistically significant.

As a whole, these numbers alleviate concerns that subjects simply randomized without exerting any mental effort when making their allocations. The average time spent reading the prospectuses should be enough for a knowledgeable subject to find the expenses in the four documents. Since participants could leave the experiment at any time they wished, time spent in the experiment likely reflects time actually spent in the decision-making process. Additional evidence against the randomization hypothesis comes from Wald tests, which can reject equality of subjects' mean allocations to each fund at the $1 \%$ level for all ten experimental subgroups.

\footnotetext{
${ }^{8}$ Approximately one-third of the MBAs and one-sixth of the college sample reported not having taken the SAT. Many of these subjects may be foreign students, which raises the concern that poor English skills or unfamiliarity with U.S. financial institutions may cause them to pay high fees. However, we find no significant difference in mean fees between student subjects who did and did not take the SAT (two-sided $p$-value of 0.54 , not reported in a table).

${ }^{9}$ The correct answer among the choices offered is short-term U.S. government bonds.

10 When a subject reported a range of time, such as " 10 to 15 minutes," we assigned the midpoint of that range to the subject. The staff and MBA figures are close to those calculated from our own records of how much time elapsed between a subject's receiving the experimental materials and his or her returning them to receive the debriefing survey. Unfortunately, we did not keep our own records of how much time college subjects took, so we cannot independently corroborate their reports.
} 


\section{Main Experimental Results}

Table 4 shows the mean portfolio fee (load plus expense ratio plus short-term redemption fee if applicable) paid in each condition by subject type, as well as the average (weighted by dollar allocation) annualized long-horizon historical return of the funds in the portfolios. Despite receiving no non-portfolio services whatsoever, the average fee paid by staff in the prospectusonly condition is $\$ 456$, which is higher than the $\$ 431$ they would have paid if they had selected randomly, and much higher than the $\$ 255$ they would have paid if they had allocated all $\$ 10,000$ to the lowest-cost fund, Allegiant. We cannot directly compare staff allocations to student allocations due to differing fund menus, but we can directly compare MBA and college student allocations. Contrary to our expectations, MBAs did no better than college students when simply provided with the mutual fund prospectuses. MBAs in the prospectus-only condition paid $\$ 421$ in fees on average, which is only $\$ 10$ less than the average college prospectus-only fee, and we cannot reject the hypothesis that the means are equal (two-sided $p=0.52$ ). The fees of the average prospectus-only student's portfolio are only slightly below the $\$ 443$ fee subjects would have paid if they had chosen randomly and well above the $\$ 309$ fee of the lowest-cost fund, Allegiant.

The black bars in Figure 1 show the average prospectus-only group allocations across the four funds. Staff and MBA prospectus-only groups allocated only 18 to $19 \%$ of their money to both the lowest-cost fund, Allegiant, and the Morgan Stanley fund. But staff allocated 15 percentage points less to the cheap UBS fund than MBAs because they invested $38 \%$ of their portfolio in the most expensive fund, Phoenix Insight (which was not offered to students). In contrast, MBAs invested only 23\% in their costly fourth option, Mason Street (which was not offered to staff).

Comparing MBA allocations to college student allocations is more straightforward because the two groups were offered the same set of funds. Both student prospectus-only groups' allocations to the two cheap funds, Allegiant and UBS, are similar- $19 \%$ and about $40 \%$, respectively. The groups' allocations differ primarily in the way they decided to allocate the portion of their portfolio devoted to expensive funds: MBAs allocated more to Mason Street than Morgan Stanley (23\% versus 18\%), whereas the relative proportions are flipped (17\% versus $27 \%$ ) for the college students. The slightly lower average fees paid by MBAs are not, however, primarily driven by their preference for Mason Street over Morgan Stanley. The more important factor is that MBAs allocated 59\% to the two cheap funds in total, whereas college students allocated a slightly lower 56\%. This total is an important determinant of portfolio fees because the two cheap funds' fees are only 11 basis points apart from each other, and the two expensive funds' fees are only 34 basis points apart, but over 200 basis points separate the cheap funds from the expensive funds.

The second row of Table 4 shows that providing the fees sheet lowered the average fee paid by $\$ 24$ for staff, $\$ 55$ for MBAs, and $\$ 21$ for college students. The drop is significant at the 5\% level for the staff and the $1 \%$ level for the MBAs, but it is insignificant for the college sample, both because of the smaller magnitude of the effect and the fact that the college sample is only a third of the size of the staff or MBA sample. ${ }^{11}$ It seems that the MBAs' sophistication manifested itself in their greater responsiveness to useful information.

Nonetheless, most MBAs did not use the information optimally. The gray bars in Figure 1 show a shift to the lowest-cost fund for the fees treatment groups relative to the prospectusonly groups. But the staff, MBA, and college subjects in the fees treatment groups still allocated

\footnotetext{
${ }^{11}$ Holding fixed the point estimate of the fee treatment effect size and the variance of subject fees, tripling the college sample size to match the MBA or staff sample size would result in the college fee treatment effect becoming significant at the $10 \%$ level.
} 
$49 \%, 20 \%$, and $37 \%$ of their assets to the two high-cost funds, respectively. The histograms in Figure 2 show that only $9 \%$ of staff subjects, $19 \%$ of MBA subjects, and $10 \%$ of college subjects in the fees treatment allocated all of their money to the lowest-cost fund. While these proportions are higher than the $3 \%$ of staff, $6 \%$ of MBAs, and $0 \%$ of college students in the prospectus-only groups who allocated all their money to the cheapest fund, they are far from the $100 \%$ one would expect under optimal choice. This result suggests that search costs for fees alone cannot explain the tendency to invest in high-fee index funds, since the fees sheet brings these search costs close to zero. ${ }^{12}$ Instead, subjects seem to value normatively irrelevant characteristics.

Given the existing evidence on mutual fund returns-chasing, a likely candidate for a non-fee characteristic that subjects desire in their index funds is high past returns. The third row of Table 4 shows portfolio statistics for subjects who received the returns summary sheet that highlighted normatively irrelevant long-horizon past returns. The returns sheet increased returns-chasing among students. MBAs' average long-horizon historical return rose from $3.06 \%$ in the prospectus-only group to $3.53 \%$ under the returns treatment, a difference that is significant at the $1 \%$ level. The college sample responded even more strongly to the irrelevant information in the returns sheet; the average return increased from $2.86 \%$ to $4.03 \%$, a change that is also significant at the $1 \%$ level. The white bars in Figure 1 show that the Mason Street fund, which has the highest long-horizon historical return offered to students, gained portfolio share at the expense of every other fund. Because we had constructed the fund menu so that fees would be positively correlated with returns since inception, chasing past returns reduced expected future returns. The MBA returns treatment group paid \$19 more on average than the MBA prospectus-only group, while the college returns treatment group paid $\$ 55$ more than the college prospectus-only group.

On the other hand, the returns sheet had no effect on staff. Staff in the returns treatment chose portfolios with an insignificantly lower average historical return than staff in the prospectusonly condition. We will discuss in Section IV a potential explanation for why the returns sheet affected students but not staff.

The possibility that subjects are confused about the nature of S\&P 500 index funds motivated our final treatment condition, in which subjects were given a page with answers to frequently asked questions about S\&P 500 index funds. The fourth row of Table 4 shows portfolio statistics for staff subjects in this treatment. Fees for this group are lower by $\$ 15$ relative to staff prospectus-only subjects, although the result is statistically significant at the $10 \%$ level only under a one-sided test. Despite the weak statistical significance, the hashed bars in the top panel of Figure 1 suggest that this drop is not just due to random variation. Both cheaper funds received more money in the FAQ treatment than in the prospectus-only condition, and both expensive funds received less money. The hashed bars in the top panel of Figure 2 show, however, that the FAQ treatment was not successful in increasing the number of subjects who chose the cheapest possible portfolio.

\section{Interpretation}

In order to gain insight into what motivated subjects' decisions in the four experimental conditions, we asked them in the debriefing survey (the staff version is reproduced in Appendix E) to rate how important eleven factors were in shaping their portfolio decision. We assign the

\footnotetext{
${ }^{12}$ The fee summary sheet did not contain information on the UBS fund's early-redemption fee, which affected only staff portfolios, although it did warn subjects, "Other fees may apply. Please check the fund's prospectus for more details." Even without the earlyredemption fee, however, the UBS fund was more expensive than the Allegiant fund, so a cost-minimizing investor's decision would not be affected by ignorance of the early-redemption fee.
} 
integers 1 through 5 to the five possible ratings, with 1 corresponding to "not very important at all" and 5 corresponding to "very important." Table 5 reports the average integer rating of each factor's importance with the associated ordinal ranking in parentheses (lower numbers indicate greater ordinal importance).

The staff and college prospectus-only groups ranked fund performance over the past year and fund performance since inception as the first- and second-most important factors respectively. Fund fees, expenses, and loads were ranked fifth by prospectus-only staff and eighth by prospectus-only college students. In light of this ranking, it seems unlikely that these subjects' search efforts were primarily directed towards finding the most relevant information about the funds-their cost.

In contrast, MBA prospectus-only subjects ranked fees as the most important factor in their portfolio decision. As previously noted, however, their fees are not significantly lower on average than the college prospectus-only subjects' fees. The minimal gain that the MBAs reaped from their prioritization of fees suggests that the cost of accurately finding fees in the prospectuses is relatively high even for MBAs and/or that the false allure of fund returns over the past year and since inception—ranked second and third by prospectus-only MBAs—and other factors is strong enough to offset the benefits of prioritizing fees.

None of the prospectus-only groups ranked brand recognition or past experience with the fund companies as higher than their sixth-most important factor in their decision. In addition, customer service quality was ranked no higher than ninth, suggesting that subjects were not mistakenly applying decision rules that are perhaps relevant in the real world but not in the experimental task. ${ }^{13}$

Providing the fees sheet elevated the ranking of fees relative to their ranking in the prospectusonly condition. Staff subjects raised fees' ordinal importance from fifth to second, and college subjects from eighth to first. MBAs in both conditions ranked fees as their most important factor, but the cardinal rating of fees in the fees treatment is higher. Staff subjects receiving the FAQ sheet also increased their relative rating of fees' importance slightly, raising their ordinal rank to fourth (versus fifth in the prospectus-only condition), although the cardinal rating of fees is lower than in the prospectus-only condition.

The returns sheet similarly elevated the relative ranking of long-horizon past returns for students. College students in the returns treatment condition ranked returns since inception as their most important factor (versus second for the prospectus-only group), downgrading the more sensible one-year return factor to second place. MBAs in the returns treatment ranked the two past performance factors first and second (versus second and third for the prospectusonly group). On the other hand, consistent with the weak effects we saw in Table 4, staff's ranking of returns' importance does not seem to have responded to the returns sheet.

These factor rankings appear to contain real information. Table 6 presents regressions—run separately for staff, MBAs, and college students—where the dependent variable is portfolio fees or long-horizon past returns. The explanatory variables are treatment group dummies and the cardinal coding of how highly the subject ranked the eleven factors. Even after controlling for the information treatments, we find that within each subject group, those who rated fees as

\footnotetext{
${ }^{13}$ Most of the prospectuses had no meaningful mentions of non-portfolio services. The exception was the Phoenix fund's prospectus, which discussed the availability of check-writing against one's account; the ability to exchange shares by calling into the customer service number; and services that would automatically deduct money from one's bank account and invest it in fund shares at a regular interval, automatically exchange a predetermined amount from one Phoenix fund to another at a regular interval, and automatically redeem a predetermined amount from the fund and deposit the proceeds in one's bank account at a regular interval.
} 
more important paid significantly less in fees. Increasing the numerical rating of fee importance by one is associated with a decrease in fees of between 15 and 19 basis points.

We also find that those who rated past returns as more important chose portfolios with higher long-horizon historical returns. The magnitude of the returns since inception effect is similar for MBAs and college students: a one unit increase in the reported importance of fund performance since inception is associated with a 15 basis point increase in the portfolio's annualized returns since inception, and this effect is significant at the 5\% level for MBAs and the 10\% level $(p=0.07)$ for college students. The returns since inception effect is positive but half the size for staff members, and misses significance at the $10 \%$ level $(p=0.12)$. Instead, for staff, importance placed on fund performance over the past year is a strongly significant correlate, with each unit rating increase associated with a 29 basis point increase in longhorizon past returns.

Examining the other factor rankings, there is nothing that is consistently correlated with portfolio fees paid. In particular, importance placed on the fund's customer service has a significant positive correlation with MBAs' portfolio fees-perhaps suggesting a misapplication of a real-life heuristic in the experimental setting-but the coefficient is small, positive, and insignificant for staff, and negative and insignificant for college subjects.

The fees and returns treatment effects are consistent with the summary sheets' lowering search costs for subjects who value low fees and high past returns but observe both with considerable noise when given only prospectuses. When a valued characteristic is observed with more precision due to the summary sheets, subjects place more weight on it.

Under this interpretation, the returns sheet's null effect on staff-despite staff subjects' high weight on past returns-implies that prospectus-only staff observed past long-horizon returns relatively precisely. This may be because staff were highly motivated by their large incentives and thus expended more effort than students in finding the past returns information. Staff, however, either did not expend as much effort finding the fees in the prospectuses or had a hard time finding them, so they did not precisely observe fees. Hence, the fees sheet had scope to shift staff portfolios towards lower-cost funds.

The fact that highly motivated investors are able to accurately identify past returns in the prospectus does not necessarily imply that mutual fund advertising highlighting past returns has no effect on investment decisions. In the real world, investors must contend with thousands of mutual funds instead of just four, so even very highly motivated investors are likely to observe most funds' past returns imprecisely prior to seeing an advertisement.

The search cost effects of the summary sheets may have been augmented by implicit advice effects, where subjects inferred that the information on the summary sheet is normatively important simply because it had been given to them by the experimenters. But if one chooses to interpret the treatment effects as arising entirely through the implicit advice channel, it is not obvious why staff heeded the implicit advice of the fees sheet but not the returns sheet.

Finally, the failure of the FAQ treatment to move subjects close to the minimum-fee portfolio may be due to the answers not being clearly understood, or our not explicitly stating that the optimal portfolio allocates $100 \%$ to the lowest-cost fund. ${ }^{14}$ Alternatively, the fees may have been too difficult to accurately identify in the prospectuses, causing subjects to place little weight on them in their portfolio decision. Subjects may also have continued to believe that

${ }^{14} \mathrm{We}$ did not include such an explicit statement because of the experimenter demand effect it would produce, which would make the FAQ treatment effect difficult to interpret. 
there is a significant amount of active management in an index fund, leading to predictable outperformance unrelated to lower fees. Fund companies may intentionally contribute to this confusion in order to soften price competition (Gabaix and Laibson, 2006;Gabaix, Laibson, and Li, 2005;Carlin, 2006). For example, the Allegiant fund's 2006 prospectus states, "However, the Adviser believes that employing certain active management strategies for a percentage of the Fund's assets, if successful, will result in net returns after expenses that may more closely approximate the returns of the S\&P 500 Index."

\section{Portfolio Choices and Subject Characteristics}

In this section, we examine how subject characteristics affected their portfolio choices. We first consider the impact of basic demographic characteristics. Table 7 regresses portfolio fees and long-horizon historical returns on age, gender, education dummies, and treatment dummies, run separately for staff, MBA, and college subjects.

Among staff subjects, we find that women paid higher fees, but there is surprisingly no relationship between education and fees. If anything, subjects who had only a high school education or less (the omitted educational category) paid the lowest fees on average. This is because low-education subjects were more prone to distribute their portfolios evenly among the four investment options instead of chasing the Phoenix Insight fund's high past returns. However, we cannot reject the hypothesis that all educational groups paid the same fees on average ( $p$-value $=0.16$ ). We do reject at the $10 \%$ level the hypothesis that all educational groups chose portfolios with the same average long-horizon past return ( $p$-value $=0.07$ ), a finding primarily driven by the high returns-chasing tendencies of those with some graduate education but no graduate degree. The significant negative coefficient on the fees treatment dummy in the fees regression indicates that the staff fees treatment effect does not arise simply because staff who were randomized into the prospectus-only group were somewhat less educated than staff who were randomized into the fees treatment group.

Among student subjects, we find that MBAs who are older and female chase past returns since inception more aggressively. We find no significant demographic correlates among the college students. Although there is little meaningful variation in educational attainment within each student group, we are able to examine the correlation between portfolio choices and SAT scores. In unreported regressions, we include total SAT scores (math plus verbal) as a control variable for student subjects, which causes our sample size to drop in half due to missing score data. We find no significant relationship between SAT scores and fees; the point estimate indicates that a 100 point rise in combined SAT score is associated with only a 3 basis point decline in fees among MBAs and a 3 basis point rise in fees among college students. ${ }^{15}$

In addition to the basic demographic characteristics discussed above, the debriefing survey completed by respondents included questions designed to gauge financial knowledge and investment confidence. The second, fifth, and eighth columns of Table 8 show the distribution of responses to questions about the likelihood of changing one's decision in response to professional advice, confidence that one's decision was optimal, self-assessed investment knowledge, and the types of investments found in a money market fund. MBAs score the highest on investment confidence and both the objective and self-assessed measures of financial knowledge. Staff subjects have intermediate levels of confidence and knowledge, and college students score the lowest on these measures.

\footnotetext{
15 In contrast, Korniotis and Kumar (2008) argue that among discount brokerage investors who hold undiversified portfolios, trade frequently, or have a strong preference for local stocks, portfolios held by those with high cognitive ability outperform portfolios held by those with low cognitive ability. However, they find that high cognitive ability investors have no advantage when they hold diversified, passive portfolios.
} 
The third, sixth, and ninth columns of Table 8 display striking negative relationships between fees and confidence, and between fees and knowledge. For example, in all three subject groups, the average fee increases monotonically with the self-reported likelihood that subjects would change their decision after consulting a professional investment advisor. The subjects who paid the highest fees themselves doubted that they were making the best portfolio allocation. Fees also generally fall with self-assessed confidence that the portfolio decision was the right one for the subject, self-assessed investment knowledge, and knowledge of the types of investments found in a money market fund. The most notable non-monotonicities occur among MBAs who consider themselves "very knowledgeable" investors and college subjects who are "very confident" about their portfolio decision; these extremely confident subjects paid higher fees than many of their less confident peers, but represent a small fraction of their respective samples (6\% of MBA and 5\% of college subjects). Staff who were "not at all confident" about their decision paid lower fees than "somewhat confident" and "less than confident" staff (due to the tendency of the least confident staff to distribute their allocations more evenly across funds than their slightly more confident peers), but this group too represents only a small fraction (7\%) of the staff sample.

In unreported regressions, we find that the negative relationship between financial knowledge/ confidence and fees is generally present even after controlling for gender, education, and information treatment. ${ }^{16}$ Therefore, responses to these survey questions are useful for predicting portfolio choice quality beyond what demographics and information conditions can tell us.

\section{Conclusion}

The wide variation of fees in the S\&P 500 index fund universe has been rationalized as reflecting heterogeneity in the value of non-portfolio services bundled with each index fund. We test this hypothesis by offering experimental subjects access to four S\&P 500 index funds' returns stripped of these non-portfolio services. The optimal portfolio allocates everything to the lowest-cost fund.

Despite this unbundling, subjects overwhelmingly failed to minimize index fund fees. Instead, subjects placed heavy weight on irrelevant attributes such as funds' annualized returns since inception. Highlighting these misleading historical returns caused student subjects (in one of our randomized experimental treatments) to chase those returns even more intensely, despite the negative future return consequences such behavior had. Even subjects who claimed to prioritize fees in their portfolio decision showed minimal sensitivity to the fee information in the prospectus. Subjects apparently do not understand that S\&P 500 index funds are commodities. In our experiment, fees paid are increasing in financial illiteracy. In the real world, this problem is likely to be exacerbated by the financial advisors whose compensation is increasing in the fees of the mutual funds they sell to their clients. When consumers in a commodity market observe prices and quality with noise, a high degree of competition will not drive markups to zero (Gabaix, Laibson, and Li, 2005; Carlin, 2006). Our results suggest that such noise helps account for the large amount of price dispersion in the mutual fund market.

Natural policy responses to suboptimal choices are to improve disclosure and educate investors. We test two such interventions and find that portfolio allocation improves modestly but remains far away from the optimum. Beshears et al. (2009) test another disclosure intervention that

\footnotetext{
${ }^{16}$ The self-reported confidence and knowledge variables are assigned an integer from 1 to 3 or 1 to 5 in the regressions. For Harvard staff, self-assessed investment knowledge, confidence, and likelihood to change one's decision are significant. For MBAs, knowledge of money market fund investments and likelihood to change one's decision are significant. For college students, self-assessed investment knowledge and confidence are significant, and likelihood to change one's decision has a $p$-value of 0.13 .
} 
provides experimental subjects a simplified summary of the prospectus and find that such an intervention yields little change in allocations among actively managed funds relative to when subjects simply receive the statutory prospectus. In sum, although better disclosure and financial education may be helpful, the evidence in this paper and Beshears et al. (2008) indicate that their effect on portfolios is likely to be modest.

Our results also suggest that developing reliable ways of eliciting agents' confidence in their own actions may prove to be a fruitful way of identifying areas in which optimization errors play an economically important role. We show that subjects who pay higher fees tend to be less sure that they are maximizing their own utility. Students taking a math exam can roughly predict whether they correctly answered a question. Economic agents may also know when they are likely to have made an error in a real-life maximization problem. Regrettably, having a sense that your choice is wrong does not necessarily tell you how to fix it.

\section{References}

Barber, Brad M.; Odean, Terrance; Zheng, Lu. Out of Sight, Out of Mind: The Effects of Expenses on Mutual Fund Flows. Journal of Business 2005;78(6):2095-2119.

Benartzi, Shlomo; Thaler, Richard. Naive Diversification Strategies in Retirement Saving Plans. American Economic Review 2001;91:79-98.

Berk, Jonathan B.; Green, Richard C. Mutual Fund Flows and Performance in Rational Markets. Journal of Political Economy 2004;112(6):1269-1295.

Beshears, John; Choi, James J.; Laibson, David; Madrian, Brigitte C. How Does Simplified Disclosure Affect Individuals' Mutual Fund Choices? 2009 Harvard mimeo.

Carhart, Mark. On Persistence in Mutual Fund Performance. Journal of Finance 1997;52:57-82.

Carlin, Bruce I. Strategic Price Complexity in Retail Financial Markets. Journal of Financial Economics. 2006 forthcoming.

Chevalier, Judith; Ellison, Glen. Risk Taking by Mutual Funds as a Response to Incentives. Journal of Political Economy 1997;105:1167-1200.

Choi, James J.; Laibson, David; Madrian, Brigitte C. Are Empowerment and Education Enough? Under diversification in 401(k) Plans. Brookings Papers on Economic Activity 2007;2005(2):151-198.

Choi, James J.; Laibson, David; Madrian, Brigitte C.; Metrick, Andrew. Reinforcement Learning and Investor Behavior. 2007 NBER Working Paper 10454.

Christoffersen, Susan EK. Why Do Money Fund Managers Voluntarily Waive Their Fees? Journal of Finance 2001;56:1117-1140.

Collins, Sean. Are S\&P 500 Index Mutual Funds Commodities? Investment Company Institute Perspective 2005;11(3)

Cronqvist, Henrik. Advertising and Portfolio Choice. Ohio State University Working Paper; 2006.

Cronqvist, Henrik; Thaler, Richard. Design Choices in Privatized Social Security Systems: Learning from the Swedish Experience. American Economic Review Papers and Proceedings 2004;94:424-428.

Elton, Edwin; Gruber, Martin; Busse, Jeffrey. Are Investors Rational: Choices Among Index Funds. Journal of Finance 2004;59:261-288.

Gabaix, Xavier; Laibson, David. Shrouded Attributes, Consumer Myopia, and Information Suppression in Competitive Markets. Quarterly Journal of Economics 2006;121:505-540.

Gabaix, Xavier; Laibson, David; Li, Hongyi. Extreme Value Theory and the Effects of Competition on Profits. Harvard University mimeo; 2005.

Gruber, Martin J. Another Puzzle: The Growth in Actively Managed Mutual Funds. Journal of Finance 1996;51:783-810.

Hendricks, Darryll; Patel, Jayendu; Zeckhauser, Richard. Hot Hands in Mutual Funds: Short-Run Persistence in Relative Performance. Journal of Finance 1993;48:93-130.

Hortaçsu, Ali; Syverson, Chad. Product Differentiation, Search Costs, and Competition in the Mutual Fund Industry: A Case Study of S\&P 500 Index Funds. Quarterly Journal of Economics 2004;119:403-456. 
Ippolito, Richard A. Consumer Reaction to Measures of Poor Quality: Evidence from the Mutual Fund Industry. Journal of Law and Economics 1992;35:45-70.

Jain, Prem C.; Wu, Johanna Shuang. Truth in Mutual Fund Advertising: Evidence on Future Performance and Fund Flows. Journal of Finance 2000;55:937-958.

John Hancock Financial Services. Insight into Participant Investment Knowledge \& Behavior: Eighth Defined Contribution Plan Survey. Boston, MA: John Hancock Financial Services; 2002.

Korniotis, George M.; Kumar, Alok. Superior Information or a Psychological Bias? A Unified Framework with Cogntive Abilities Resolves Three Puzzles. Mimeo, University of Texas at Austin; 2008.

Mullainathan, Sendhil; Shleifer, Andrei. Persuasion in Finance. 2005 NBER Working Paper 11838.

Sapp, Travis; Tiwari, Ashish. Does Stock Return Momentum Explain the 'Smart Money' Effect? Journal of Finance 2004;59:2605-2622.

Sirri, Erik R.; Tufano, Peter. Costly Search and Mutual Fund Flows. Journal of Finance 1998;53:15891622.

Zheng, Lu. Is Money Smart? A Study of Mutual Fund Investors' Fund Selection Ability. Journal of Finance 1999;54:901-933.

\title{
Appendix A. Staff Investment Choice Sheet
}

\author{
Subject number:
}

Please allocate \$10,000 among the S\&P 500 index funds listed below. You may choose to allocate all $\$ 10,000$ to one fund or allocate your investment evenly or unevenly across as many funds as you like.

We will calculate how much money a real investor would get back if he or she sent $\$ 10,000$ to the funds below according to the allocation that you choose, assuming that each fund received the investment at 3:00 P.M. on August 31, 2007, and the investments were sold at 3:00 P.M. on Friday, September 28, 2007 (the last business day of September). If the investment is worth more than $\$ 10,000$ at the end of September 28, 2007, we will pay you the investment profit (the investment value minus $\$ 10,000$ ). If the investment is worth less than $\$ 10,000$ at the end of the period, you will not be responsible for these losses. This is a risk-free opportunity to win a potentially large reward.

\section{PAYOFF CALCULATION EXAMPLES}

Example \#1: Suppose selling your hypothetical investment on September 28, 2007 would give you $\$ 11,000$. Then we would pay you $\$ 1,000$, the difference between your original investment and your final investment value at the end of September (in addition to the $\$ 10$ participation payment you will receive today).

Example \#2: Suppose selling your hypothetical investment on September 28, 2007 would give you $\$ 8,500$. Since your final account balance is less than $\$ 10,000$, you would not be paid for your investment (but you would still keep the $\$ 10$ participation payment you will receive today).

Below is the menu of S\&P 500 index funds from which you may choose.

- Write the dollar amount you would like to allocate to each fund in the last column

- You may invest in as many or as few funds as you choose

- Please be careful to allocate a total of exactly $\$ 10,000$

- If you put money in a fund, that amount must satisfy the minimum opening allocation requirement 


\begin{tabular}{|c|c|c|c|}
\hline Mutual Fund & Symbol & $\begin{array}{c}\text { Minimum Opening Allocation } \\
\text { if Buying Shares in Fund }\end{array}$ & $\begin{array}{c}\text { Your Allocation in Dollars } \\
\text { (column must sum to \$10,000) }\end{array}$ \\
\hline $\begin{array}{c}\text { Allegiant S\&P 500 Index } \\
\text { Fund - Class A }\end{array}$ & AEXAX & $\$ 500$ & \\
\hline $\begin{array}{c}\text { Morgan Stanley S\&P 500 } \\
\text { Index Fund - Class A }\end{array}$ & SPIAX & $\$ 1,000$ & \\
\hline $\begin{array}{c}\text { Phoenix Insight Index Fund } \\
\text { - Class A }\end{array}$ & HIDAX & $\$ 500$ & \\
\hline $\begin{array}{c}\text { UBS S\&P 500 Index Fund - } \\
\text { Class A }\end{array}$ & PSPIX & $\$ 1,000$ & \\
\hline
\end{tabular}

\section{$\rightarrow$ The prospectuses for these $\mathbf{4}$ funds are attached $\leftarrow$}

Any portfolio allocations which violate minimum opening allocation requirements or which fail to total $\$ 10,000$ will be ineligible for the investment payout.

\section{Appendix B. Staff Fees Summary Sheet}

\section{FEE INFORMATION}

- Mutual funds charge fees to investors.

- Some mutual funds charge a one-time fee when you purchase shares. This fee is called a front-end load and is a fixed percent of your purchase amount.

- Mutual funds also charge an ongoing fee that is a predetermined fraction of the fund balance. Over the course of one year, the total ongoing fee approximately equals:

(Your average fund balance) $\times$ (The fund's expense ratio)

- Other fees may apply. Please check the fund's prospectus for more details.

\section{TABLE OF FEES}




\begin{tabular}{|c|c|c|c|c|}
\hline 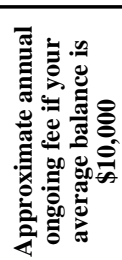 & $\stackrel{8}{\circ}$ & $\underset{\leftrightarrow}{\Delta}$ & 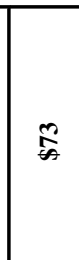 & $\stackrel{R}{*}$ \\
\hline 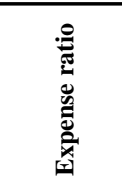 & 递 & 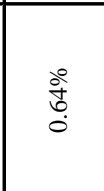 & مٌ & $\begin{array}{l}\stackrel{\circ}{\circ} \\
\stackrel{0}{0}\end{array}$ \\
\hline 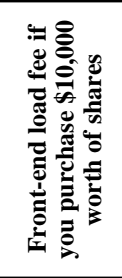 & 票 & 党 & 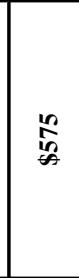 & 商 \\
\hline 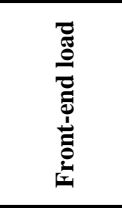 & 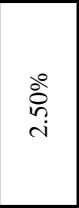 & 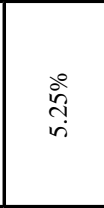 & 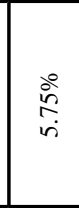 & $\begin{array}{l}\text { 今. } \\
\text { in } \\
i\end{array}$ \\
\hline 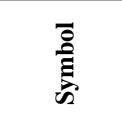 & $\begin{array}{l}\text { 希 } \\
\text { 畜 }\end{array}$ & 希 & \begin{tabular}{|l|l}
$x$ \\
希
\end{tabular} & 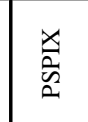 \\
\hline 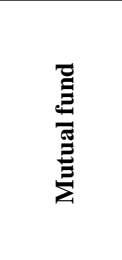 & 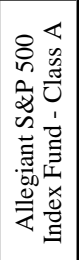 & 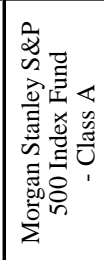 & 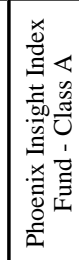 & 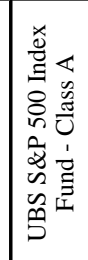 \\
\hline
\end{tabular}

Rev Financ Stud. Author manuscript; available in PMC 2011 April 1. 


\begin{tabular}{|l|l|}
\hline \multicolumn{1}{|c|}{ Front-end load example } \\
$\begin{array}{l}\text { If you purchase } \$ 10,000 \text { worth of shares in a } \\
\text { fund and the front-end load is } 2.5 \% \text {, then you } \\
\text { would pay } \\
\begin{array}{c}\$ 10,000 \times 2.5 \%=\$ 250 \\
\text { in load fees at the time of purchase. }\end{array}\end{array}$ & $\begin{array}{l}\text { Expense ratio example } \\
\text { If the average balance is } \$ 10,000 \text { and the } \\
\text { expense ratio is } 0.60 \%, \text { then an investor } \\
\text { would pay approximately } \\
\$ 10,000 \times 0.60 \%=\$ 60 \\
\text { in ongoing fees over the course of one year. }\end{array}$ \\
\hline
\end{tabular}

\section{Appendix C. Staff Returns Summary Sheet RETURN INFORMATION}

\begin{tabular}{|c|c|c|}
\hline Mutual Fund & Symbol & $\begin{array}{c}\text { Average Annual Return } \\
\text { (During Longest Time Period } \\
\text { Reported in Fund's Prospectus) } 1\end{array}$ \\
\hline Allegiant S\&P 500 Index Fund - Class A & AEXAX & $3.1 \%^{2}$ \\
\hline $\begin{array}{c}\text { Morgan Stanley S\&P } 500 \text { Index Fund - } \\
\text { Class A }\end{array}$ & SPIAX & $3.6 \%^{3}$ \\
\hline Phoenix Insight Index Fund - Class A & HIDAX & $7.3 \% 4$ \\
\hline UBS S\&P 500 Index Fund - Class A & PSPIX & $3.8 \% 5$ \\
\hline $\begin{array}{l}\text { Includes the effect of fees, expenses, and s } \\
210 / 15 / 1998-12 / 31 / 2005 \\
09 / 26 / 1997-12 / 31 / 2005 \\
401 / 01 / 1997-12 / 31 / 2006 \\
510 / 02 / 1998-12 / 31 / 2005\end{array}$ & les loads, $\mathrm{b}$ & not taxes. \\
\hline
\end{tabular}

\section{Appendix D. Staff FAQ Sheet FREQUENTLY ASKED QUESTIONS (FAQS)}

$Q_{\text {Uestion 1: What is a mutual fund? }}$

Answer: A mutual fund invests money on your behalf.

Any money you give a mutual fund to manage will earn the same percent return as the investments the mutual fund holds, minus the fees the mutual fund charges you for its services.

\section{Question 2: What is an S\&P 500 index fund?}

Answer: An S\&P 500 index fund is a mutual fund that tries to make its pre-fee investment return approximate the S\&P 500 Index's investment return.

\section{Question 3: What is the S\&P 500 Index?}

Answer: The S\&P 500 Index measures the total stock market value of 500 of the largest U.S. companies. It is one of the most widely used stock market indexes in the world.

The investment return of the S\&P 500 Index is the percent change over time in the total stock market value of these 500 companies. 


\section{Appendix E. Staff Debriefing Questionnaire}

Please complete this short questionnaire and return it to be eligible for receiving payment.

1. Age:

2. Gender (please circle): Male / Female

3. What is the highest level of education listed that you have completed? (Check only one.)

$$
\begin{aligned}
& \square \text { Some high school } \\
& \square \text { High school graduate } \\
& \square \text { First year of college } \\
& \square \text { Second year of college } \\
& \square \text { Third year of college } \\
& \square \text { College graduate }
\end{aligned}
$$

4. In the previous task, you were asked to allocate $\$ 10,000$ among four different mutual funds. How important were the following factors in shaping your final investment decision? (Please check the appropriate boxes.) 


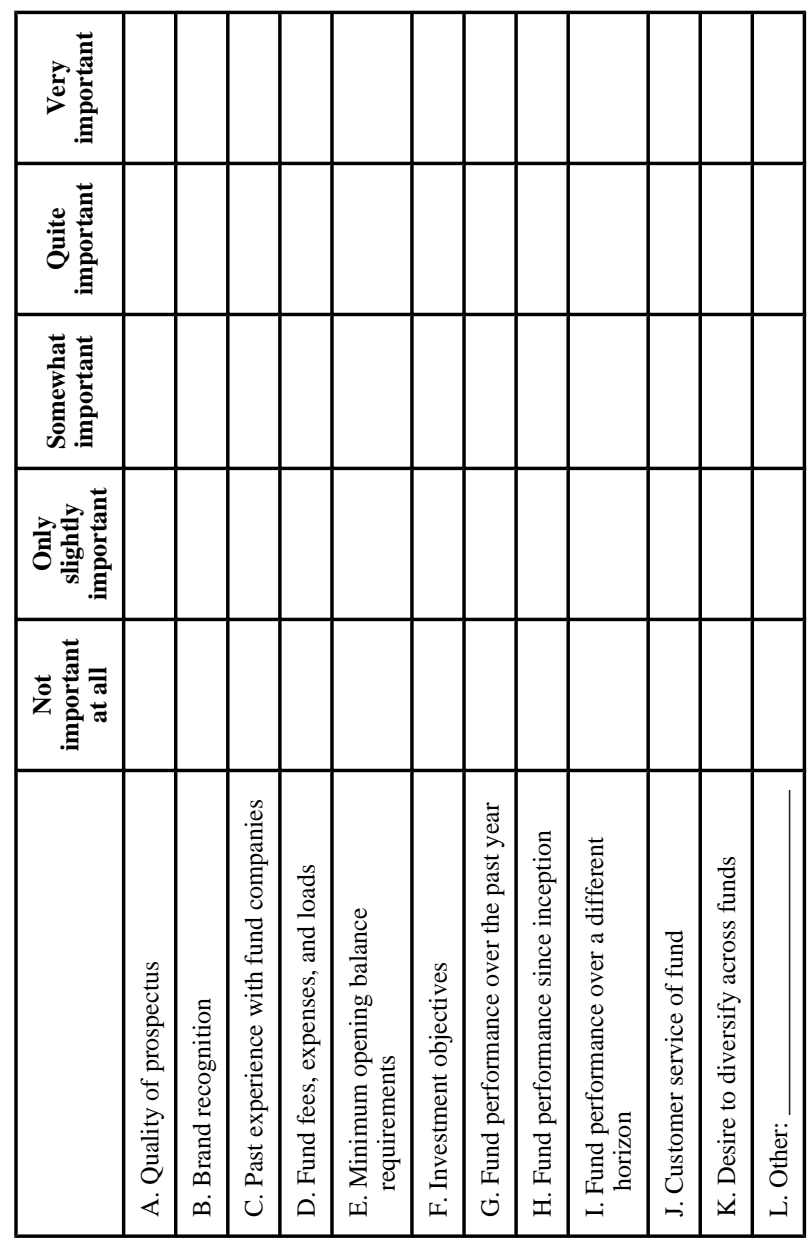

Rev Financ Stud. Author manuscript; available in PMC 2011 April 1. 
5. How likely is it that you would change your decision if you consulted a professional investment advisor? (Please check only one box.)

$\square$ Very likely

$\square$ Somewhat likely

$\square$ Not likely

6. Did you look at the funds' prospectuses to help you make your decision?

$\square$ Yes If so, for how long? Approximately minutes

$\square$ No

7. How confident are you that the decision you made is the right one for you? (Please check only one box.)

$\square$ Very confident

$\square$ Relatively confident

$\square$ Somewhat confident

$\square$ Less than confident

$\square$ Not at all confident

8. How knowledgeable an investor do you consider yourself to be? (Please check only one box.)

$\square$ Very knowledgeable

$\square$ Relatively knowledgeable

$\square$ Somewhat knowledgeable

$\square$ Less than knowledgeable

$\square$ Not at all knowledgeable

9. Please rate each of the following investments' riskiness on a scale of 1 to 5 .

(1 indicates "no risk" and 5 indicates "very high risk." Circle the appropriate number.)

\begin{tabular}{lllllll}
\hline & No risk & \multicolumn{3}{c}{ Very high risk } \\
(a) A large U.S. stock mutual fund & 1 & 2 & 3 & 4 & 5 & $\square$ Don't know \\
(b) A savings account at your bank & 1 & 2 & 3 & 4 & 5 & $\square$ Don't know \\
(c) U.S. corporate bonds & 1 & 2 & 3 & 4 & 5 & $\square$ Don't know \\
(d) Stable value/money market fund & 1 & 2 & 3 & 4 & 5 & $\square$ Don't know \\
(e) Stock of a typical Fortune 500 company & 1 & 2 & 3 & 4 & 5 & $\square$ Don't know \\
(f) An international stock mutual fund & 1 & 2 & 3 & 4 & 5 & $\square$ Don't know \\
(g) An emerging markets stock mutual fund & 1 & 2 & 3 & 4 & 5 & $\square$ Don't know \\
\hline
\end{tabular}

10. What return do you expect the following asset types to earn annually, on average, during the next five years? (Please give your best guess. If you expect an asset type to lose money on average, write a negative number.)

U.S. stocks $\%$ 


U.S. corporate bonds __ $\%$
Money market funds __ $\%$
Stable value funds __ \%

11. Which of the following types of investments are found in a money market fund? (You may check more than one type.)

$\square$ Short-term U.S. government bonds

$\square$ Corporate bonds

$\square$ Stocks

$\square$ None of the above 


\section{Harvard staff}

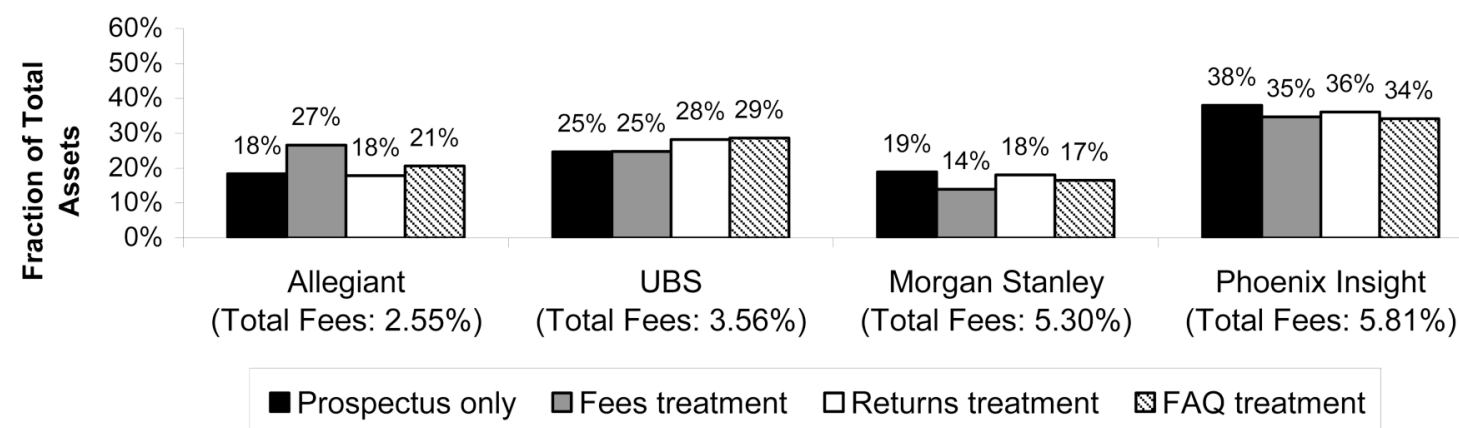

MBAstudents
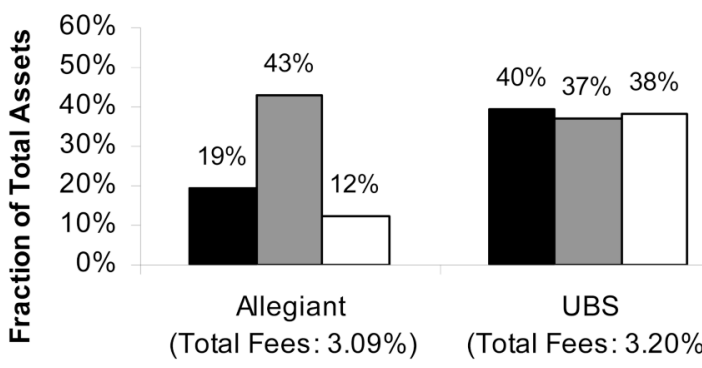

UBS

(Total Fees: $3.20 \%$ )

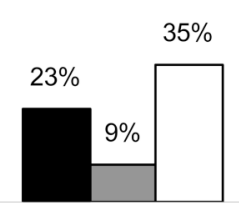

Mason Street (Total Fees: $5.55 \%$ )

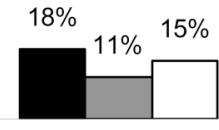

Morgan Stanley (Total Fees: $5.89 \%$ )

- Prospectus only

$\square$ Fees treatment

$\square$ Returns treatment

\section{College students}
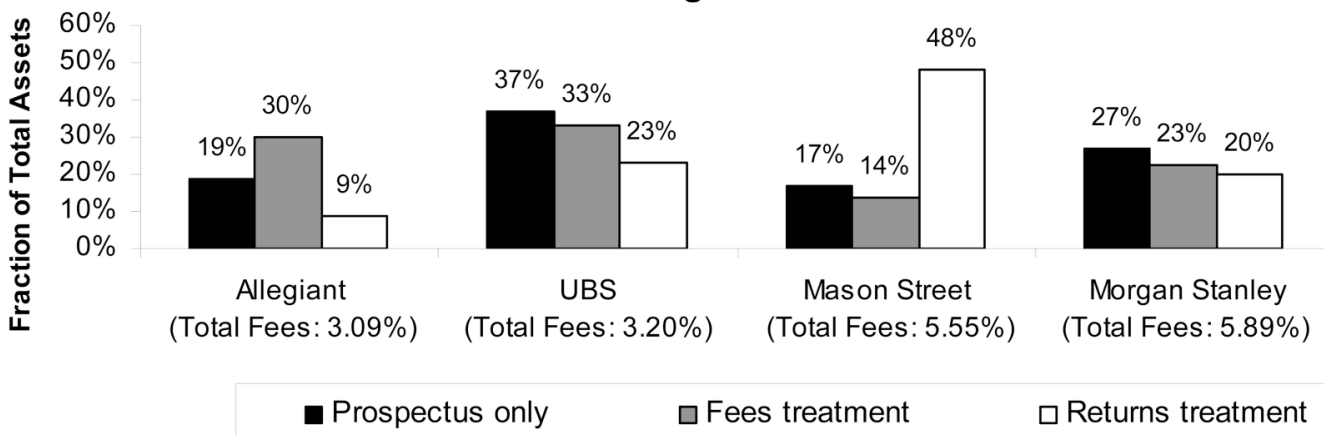

Figure 1.

Average Fund Allocations by Subject Group and Experimental Condition 


\section{Harvard staff}

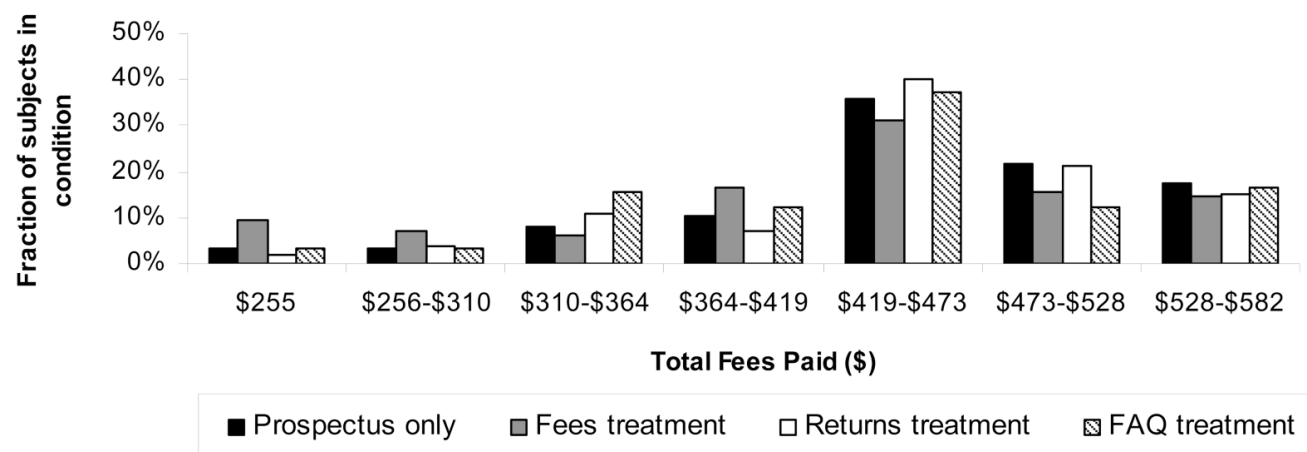

MBA students

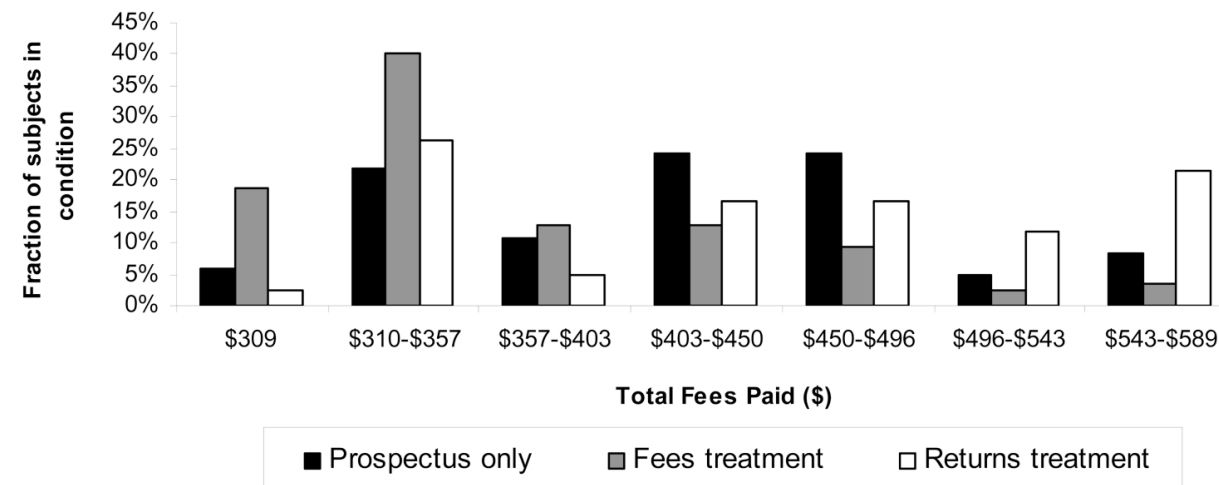

College students

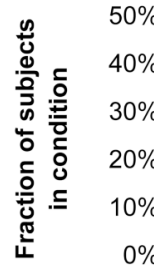

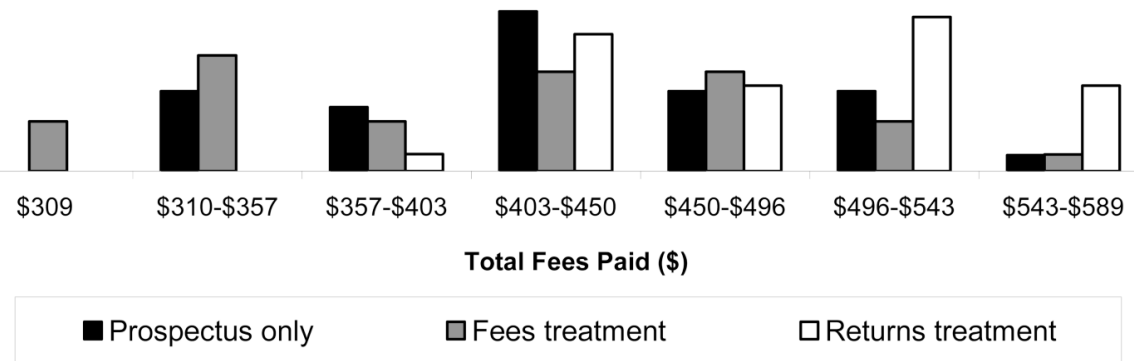

Figure 2.

Histogram of Fees Paid by Subject Group and Experimental Condition 


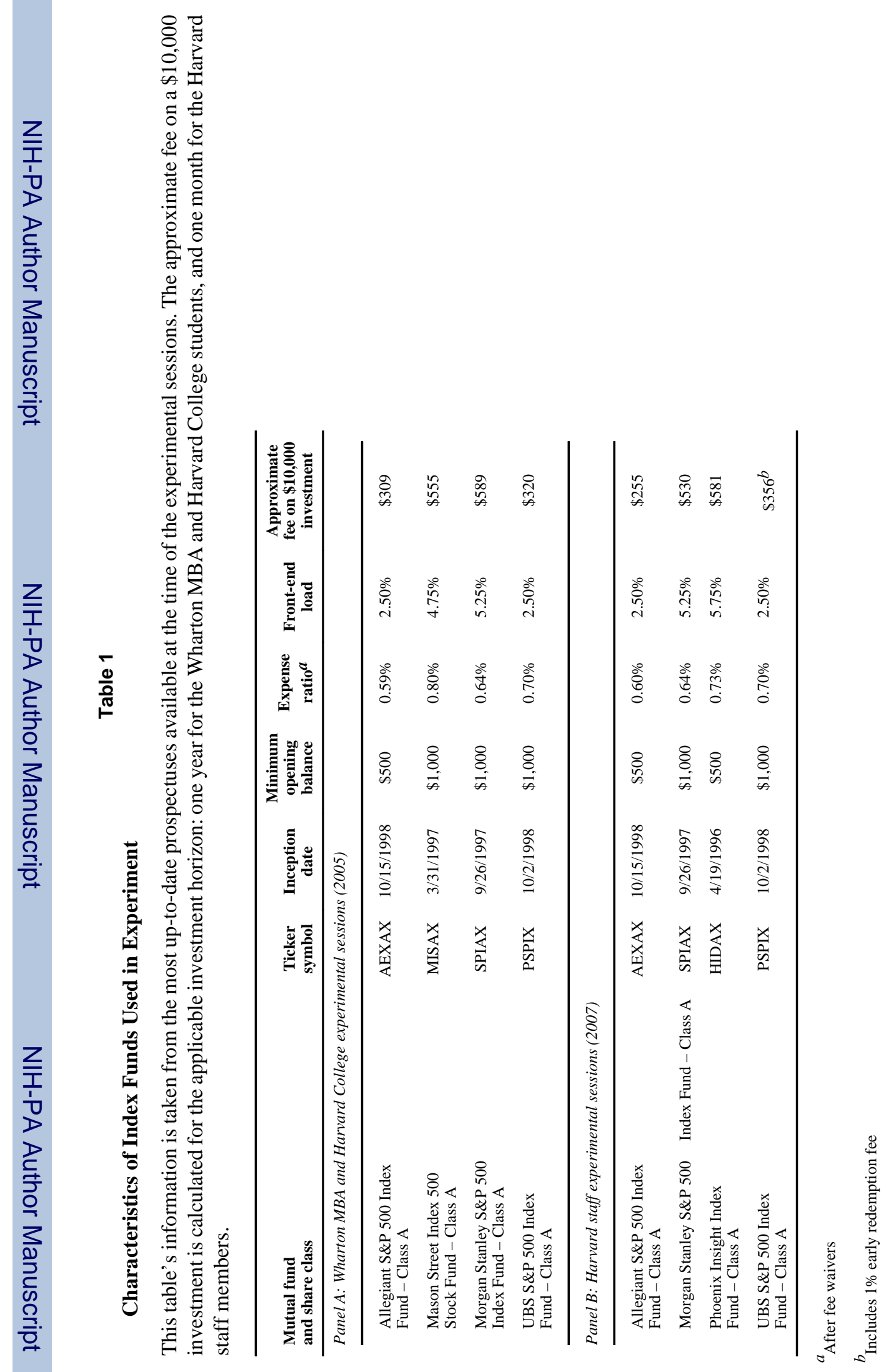




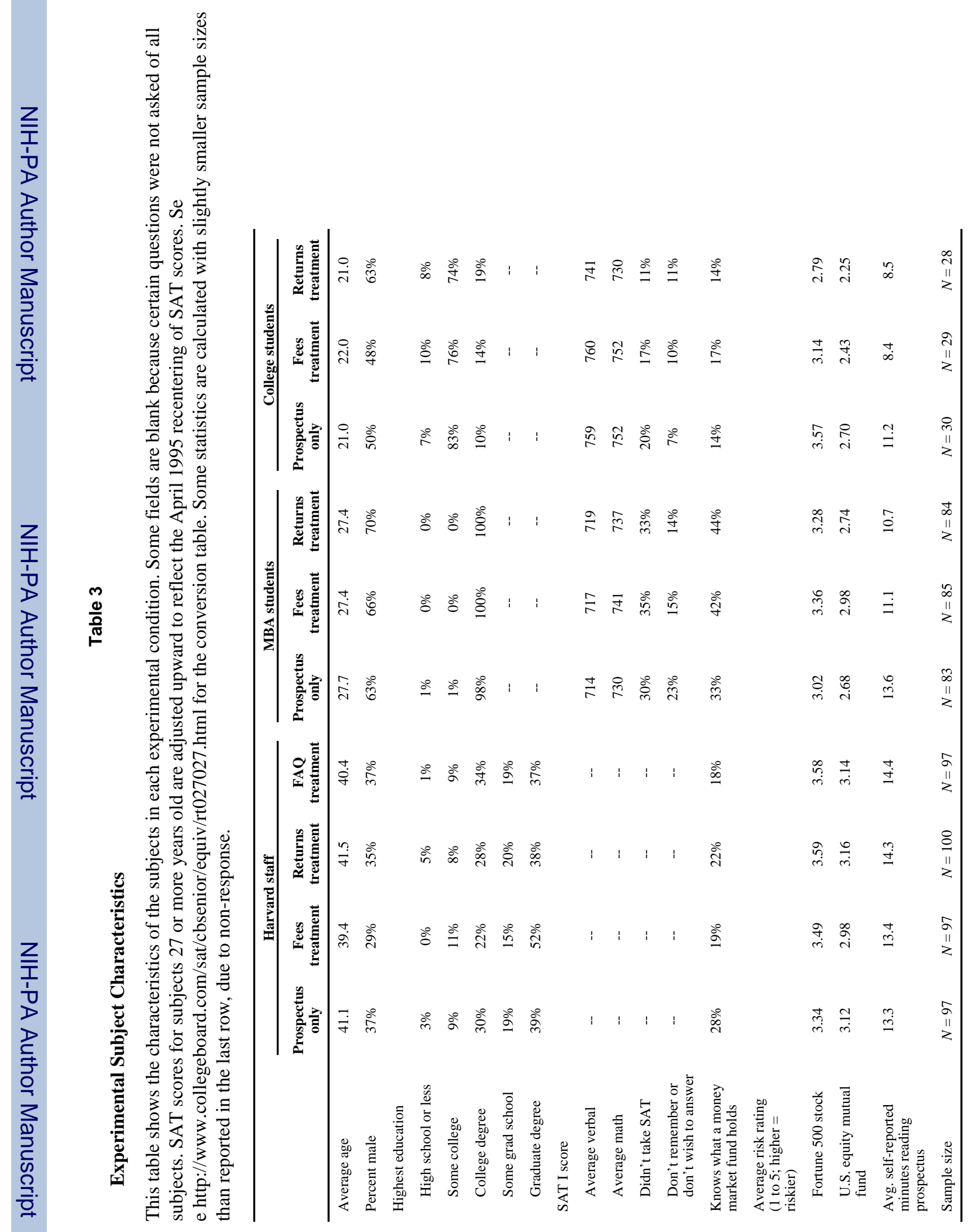

Rev Financ Stud. Author manuscript; available in PMC 2011 April 1. 


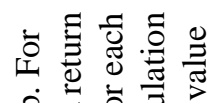

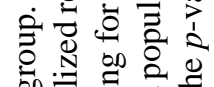

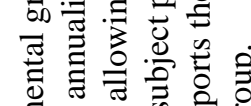

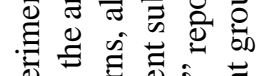

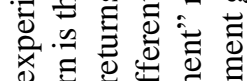

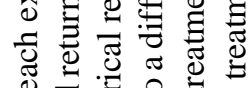

ते .⿹丁口

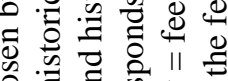

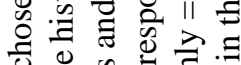

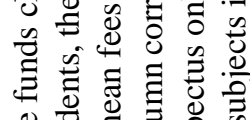

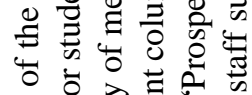

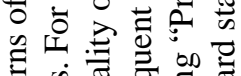

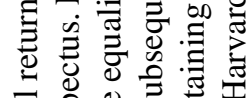

तॉ

证

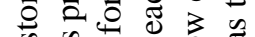

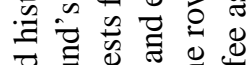

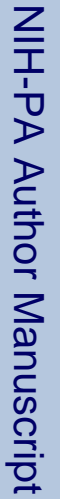

,

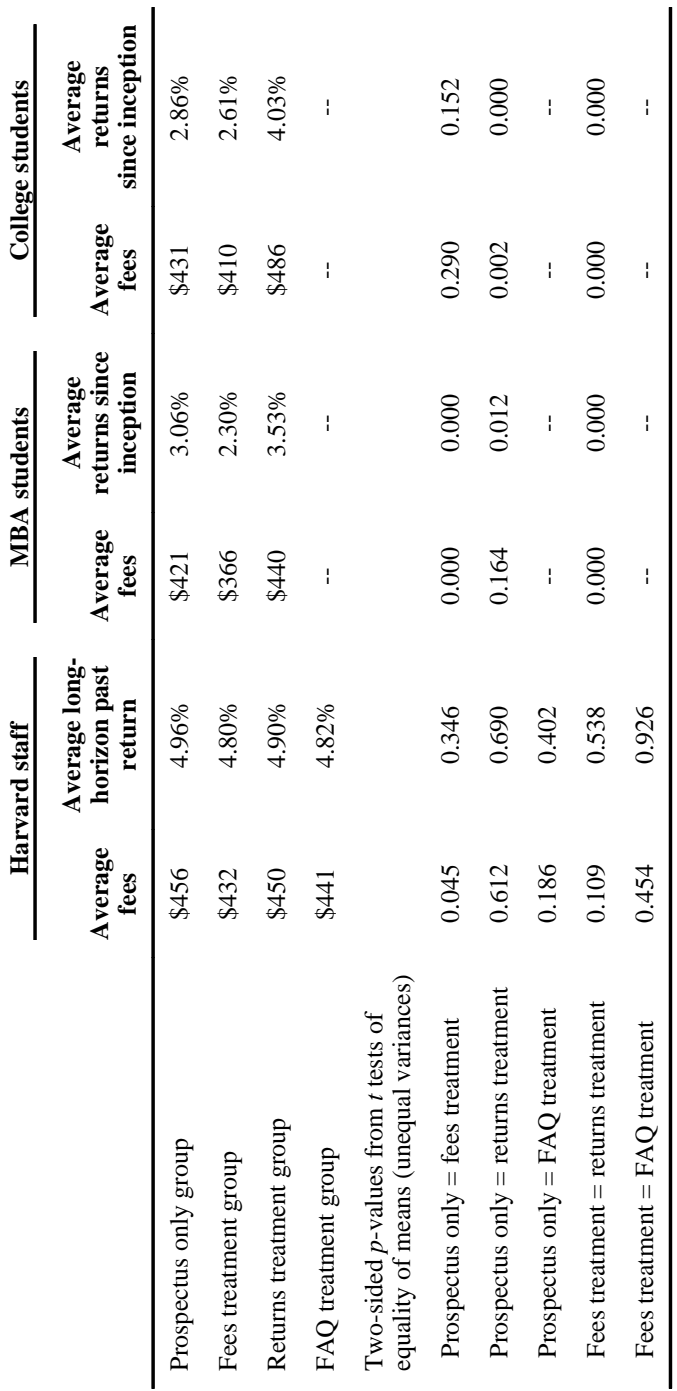

Rev Financ Stud. Author manuscript; available in PMC 2011 April 1. 


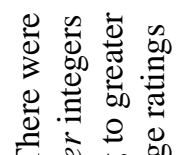

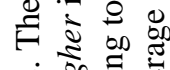

完:

क

on 0 范

.

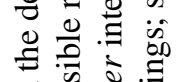

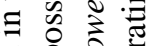

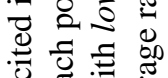

:

is is

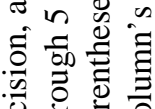

远造

陆

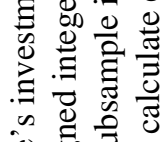

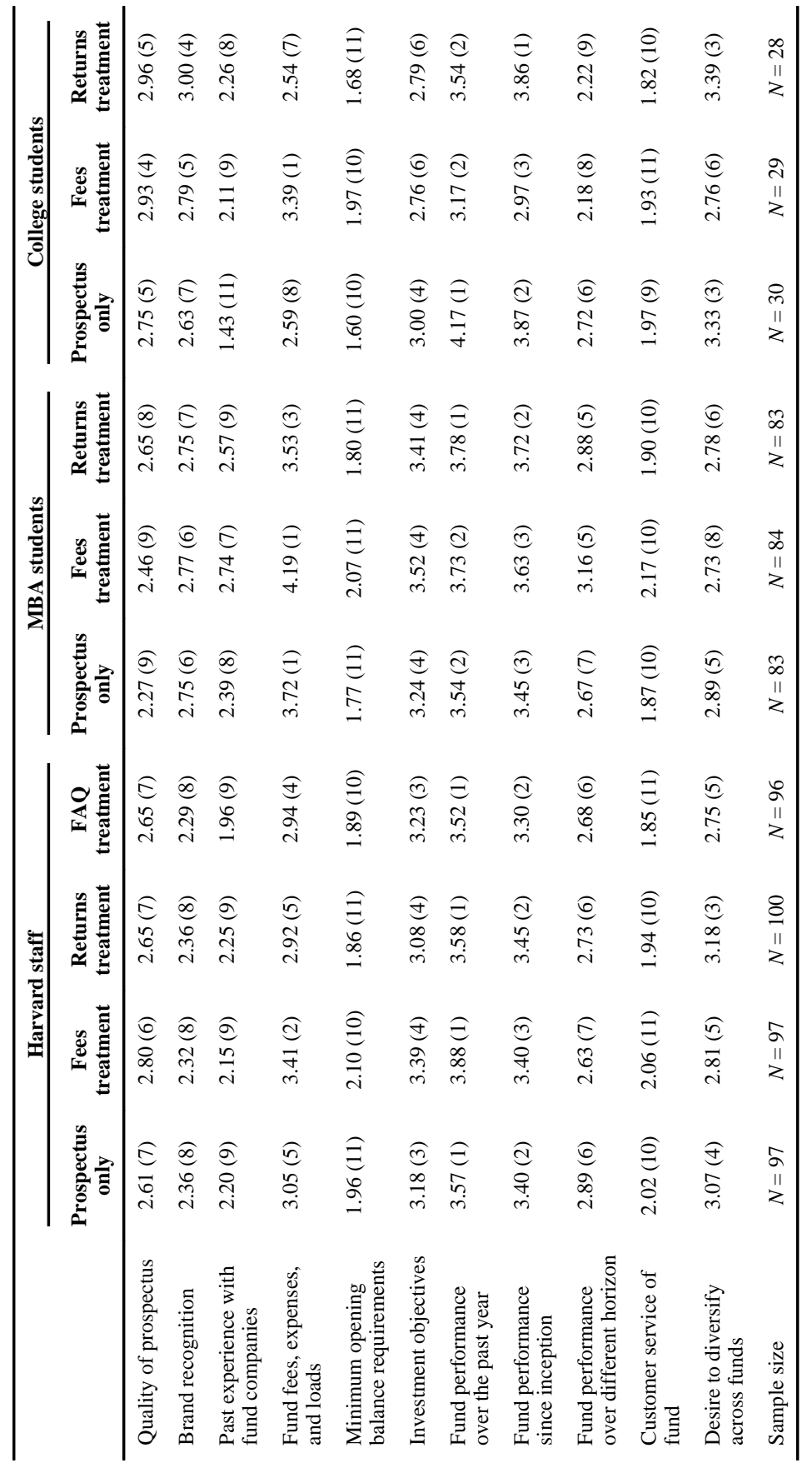




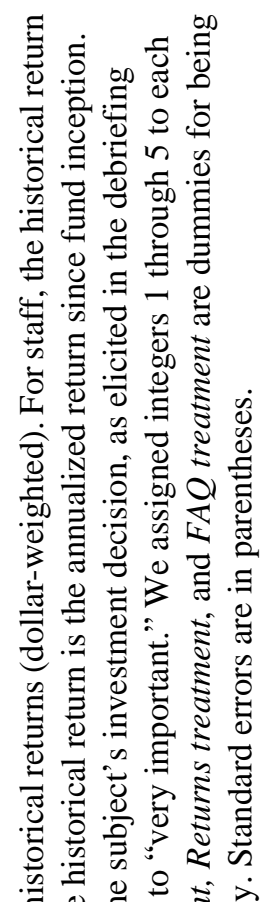




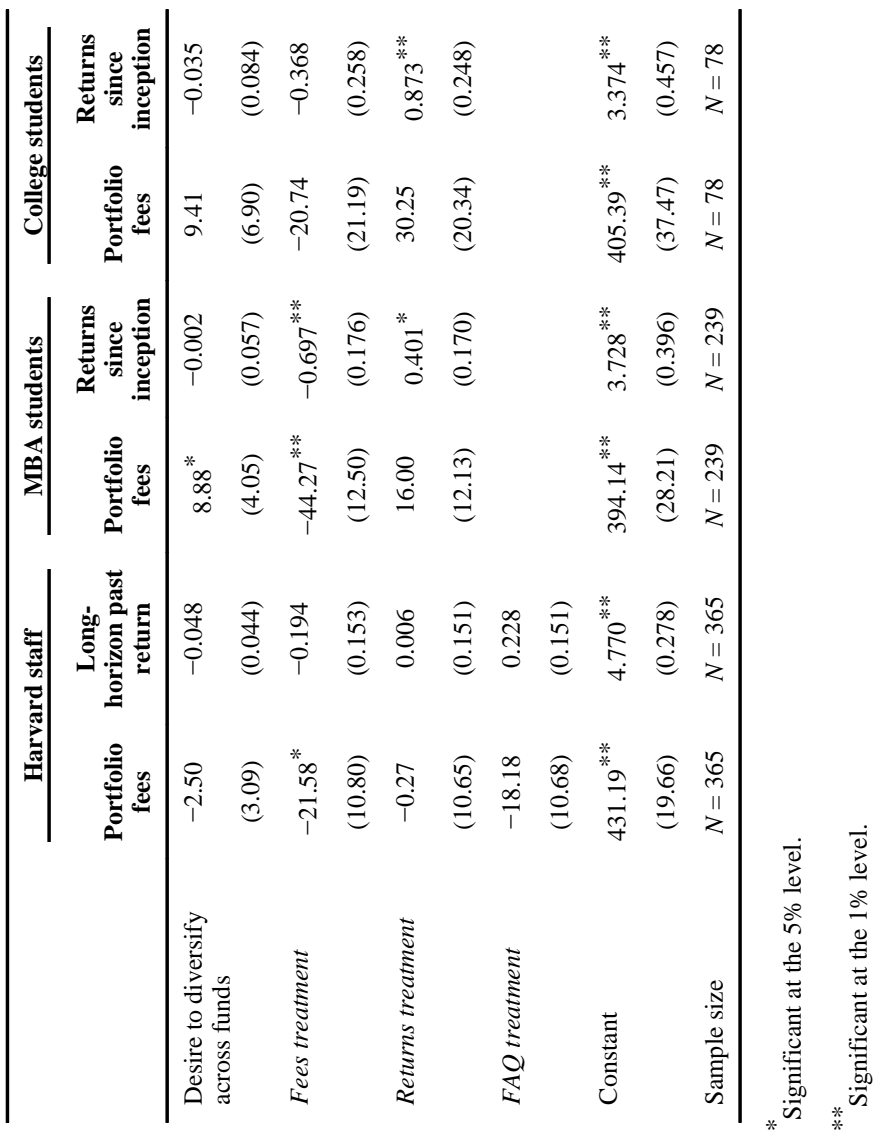

Rev Financ Stud. Author manuscript; available in PMC 2011 April 1. 


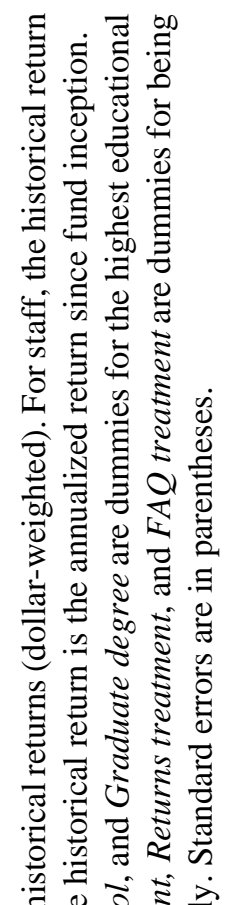




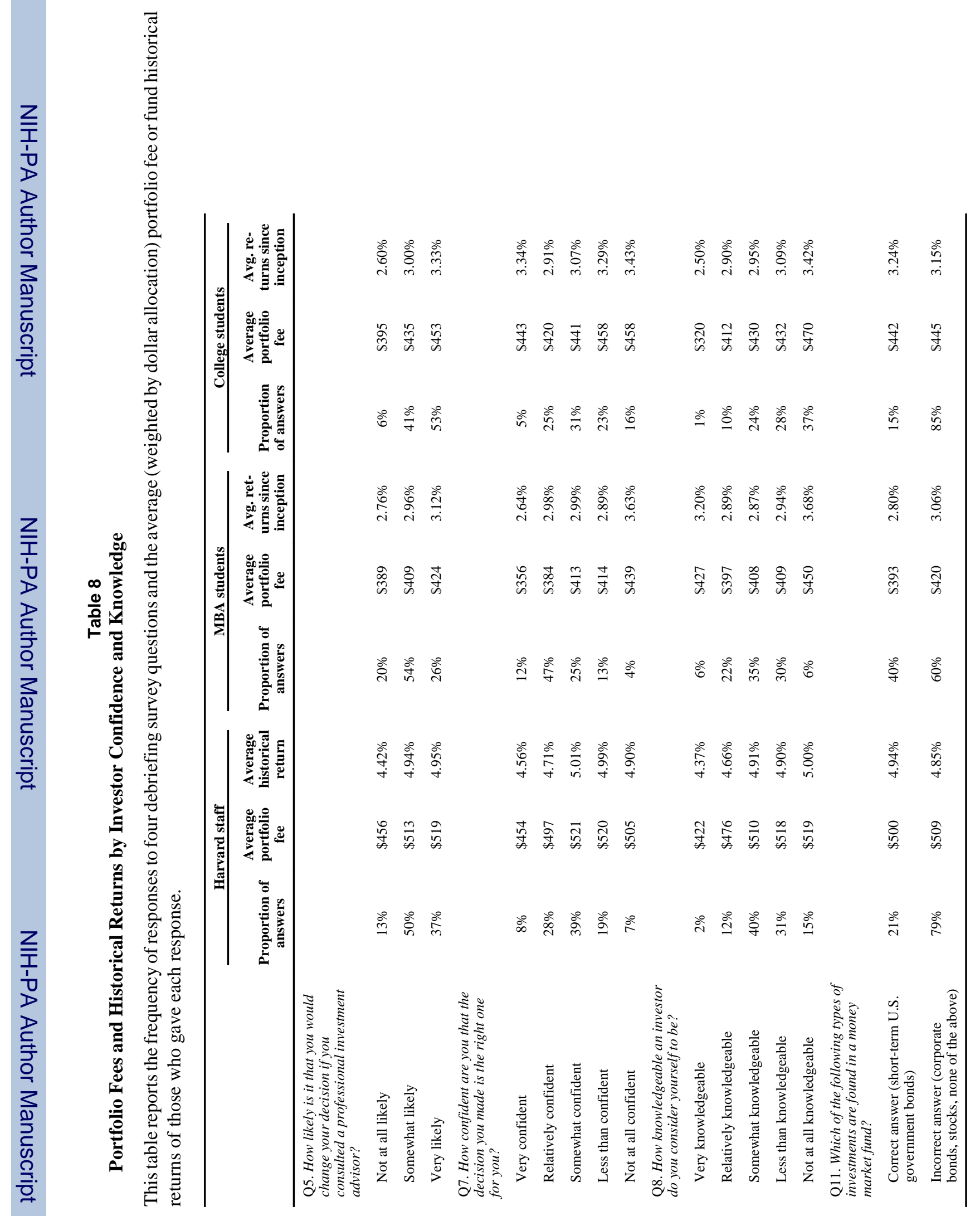

Rev Financ Stud. Author manuscript; available in PMC 2011 April 1. 